\title{
Managing Ethnic and Cultural Diversity For Political Development In Africa: A Case Study of Nigeria
}

\author{
Adediran, Adedapo ${ }^{1}$ Okaiyeto, Simon Ayodele ${ }^{2}$ Olaogun, Micheal Sunkanmi ${ }^{3}$ Oluwadele, L. Bolutife ${ }^{4}$ \\ 1. International relations and cultural diplomacy(MA), Hochschule Furtwangen University. \\ Adediranadedapo0@gmail.com \\ 2. Mass Communication Department, Salem University, Lokoja, Nigeria. okaiyetos@gmail.com \\ 3. Pan Africa Youth Democracy Fellow, Honorary Emissary, Internationalism (India) \\ michealolaogun2014@gmail.com \\ 4. Doctoral Candidate, Public Policy and Administration, Walden University, USA \\ bolutife.oluwadele@gmail.com
}

\begin{abstract}
In particular, Africa and Nigeria have their lion share of ethnic and cultural diversity problems that seem to defer solutions. Moreover, if these problems are not managed, the country's quest for political development will always be frustrated by ethnic and cultural jingoism. Therefore, this study investigates how Africa can manage its ethnic and cultural diversity for effective political development through Nigeria's prism as a case study. A qualitative study in which content analysis of secondary material and in-depth interview of 25 academicians and experts in Nigeria and Africa cultural and ethnic historical realities was conducted. The study found the factors that encourage cultural and ethnic diversity among Nigerians, including language barriers, partisan politics, marginalization, economic deprivation, and religious bigotry. The ways to manage cultural and ethnic diversity are protecting cultural, religious, and language rights of minorities; promotion of inclusive narratives and socialization mechanisms; institutionalization of federal character; justice and fairness in formal and informal institutions; establishment of inter-religious council and establishment of the inter-ethnic council. Factors that can determine national identity that is important for the unification of the people are promoting national symbols, promoting national integration, promoting public culture, recognizing minority rights, institutionalizing citizenship, and adopting a unified language. The ways to manage ethnic and cultural diversity for political development are modernization, inclusive political institutions, adoption of a unified language, diversification of economic base, inclusive development projects, employment generation/poverty reduction, and strengthening community representatives.
\end{abstract}

Keywords: Africa, Ethnicity, Culture, Conflict, Political Development, and Nigeria

DOI: $10.7176 / \mathrm{IAGS} / 90-06$

Publication date: April 30th 2021

\section{Introduction}

No doubt, continental Africa is the most ethnically and culturally divided society globally. Diverse cultural and ethnic cocoons with myriads of dialect usually culminate in conflicts because of the diversity of interests struggling to control political resources. Thus, her composition's plurality has made national integration a considerable challenge in the continent (Ojo, 2016), a severe issue for the states to harness its abundant human and natural resources for the continent's development.

Nigeria, the country with the highest ethnic and cultural diversities in Africa, has national political development among its significant challenges, begging for viable solutions. It is a country that has typical characteristics of the nature of Africa issues that bedeviled it.

Though managing ethnic and cultural diversity for political development in Africa is the problem that concerns scholars in the continent; however, there are limited studies that interrogated the area (Lucia \& Aixela, 2013; 
Edewor, Aluko \& Folarin, 2014) for a possible and working solution. Hitherto, Africa's political development is a concern for the continent leaders and its people and affects other continents such as Europe, Asia, and North America. For instance, ethnic, cultural, political, economic, and religious conflicts in Africa affect Europe as we see the issue of immigration crisis and terrorism in European nations caused by depressed Africans crossing the Mediterranean Sea.

Nigeria has its lion share of the ethnic and cultural diversity problems that seem to defy solutions. Furthermore, if these problems are not managed, the country's quest for political development will always be frustrated by ethnic and cultural jingoism. Therefore, this study proposes to explore how Africa can manage its ethnic and cultural diversity for effective political development through Nigeria's prism as a case study.

\section{Research Questions}

Finding answers to the following questions will provide evidence for the problem of this study:

1. What are the things that Nigeria should do to manage its ethnic and cultural diversity for national identity?

2. How can Nigeria manage its ethnic and cultural diversity for its political development?

\section{LITERATURE REVIEW}

\section{Ethnicity and Culture}

There is consensus among scholars and researchers on the dynamic and complex nature of the concept of ethnicity. However, Irobi (2013) understood ethnic groups as people with common heritage and descent who share language and cultural costumes, shared history, religion, and residence.

The concept of ethnicity highly researched by scholars is deeply related to the universal practice of alienation and identity branding. In contrast, branding has always characterized both intra-global and intranational relations. Also, opportunities, rights, and privileges are functions of who you are and where you are from as separated from others(Odeyemi,2014). To Osaghae 1995 (as cited by Edewor, Aluko \& Folarin,2014:2), ethnicity is conceptualized as "the employment or mobilization of ethnic identity and difference to gain an advantage in competition situations conflict or cooperation."

In his study, Irobi (2014) traced the origin of ethnicity as an attempt to classify people into a group, not according to their current nationality, but according to commonalities in their cultural and social background. Thomson (2000: 58) sees an Ethnic group as "a community of people who have the conviction that they have a common identity and common fate based on issues of origin, kinship ties, traditions, cultural uniqueness, shared history and possibly shared language." Ukpo (1977) corroborates Thomson's position as he calls an "ethnic group" a "group of people having a common language and cultural values." Ayatse and Akuva(2013: 180) perceptive work observed that ethnicity is the deliberate and conscious tracing of one's identity to a particular ethnic group and allowing such feeling to determine the way one relates with people and things, ethnicity creates the brackets of 'we' 'us' 'they' 'ours,' 'theirs' feeling. Ethnicity makes it very difficult for different ethnic groups to agree on issues because individuals usually look at anything from their idiosyncrasy or cultural prism.

There is a unified understanding of the culture around the globe, unlike globalization. Culture is seen as a way of life. Enahora (1989) noted that culture is the unifying force in the diverse Nigerian society. This may be true as Umar, Mustapha, and Muhammed's (2013) definition of culture considers the Africa and Nigeria society unification. They observe that culture constitutes "the totality of peoples way of life, including how they live, eat, dress, traditional norms, the way they are born, the way they bury the dead' and fabric for social interaction (Umar et al. 2013: 1). No doubt, culture is the identity of individuals, groups that constitute a given society. This is to say each society ought to have its own distinct cultural identity. 
Brown \& Shumba, in Nsamenang \& Tchombe, (2011) studies, noted that cultural diversity presupposes a society of various ethnic, linguistic, social, customs, and religious differences. It demands a positive approach to tolerance. Such ethnic diversity obliges recognition, tolerance, and respect of the modes of behavior and customs of each ethnic group. Cultural diversity poses a significant challenge for nation-building. Nation-building implies constructing or structuring a national identity using the state's power (Deutsch \& Foltz, 2010). Nation-building aims to unify people within the state to remain politically stable and viable by fostering social harmony, economic growth, military conscription, and national content mass schooling (Darden \& Grzymala-Busse, 2006).

\section{Ethno-Religious Crises in Nigeria}

Nigeria, a multiethnic and religious entity, has over 250 ethnic groups, with Christianity and Islam as the two major religions have, over the years, tried to outwit each other in terms of belief, adherence, structure, and growth, frustrating the union. Consequently, fanaticism was introduced into the religious practice, and ethnic superiority was introduced playing in ethnicity. Unfortunately, the adherence to faith and ethnic conformity has become a source of strife, anarchy, and bloodletting in Nigeria in recent times (Basorun, 2015 \& Onuegbu, 2013).

The idea of religion suggests man's attempt to work out a relationship with a super-ordinate being often epitomized in God. Implicit in this is an interaction between religion and the society within which it functions. Consequently, because it tended to color relationships, religion in Nigeria has significantly influenced politics and crisis, playing significant roles in the entire societal process (Egwu, 2001).

A religious and ethnic divide separates Christians and Muslims, Hausa, Igbo, Yoruba, and others, and longstanding intra/inter-religious and intra/inter-ethnic crises further divide the people. Ethnic differences complicate the pattern of adherents of Islam and Christianity. The ethno-religious crisis in Nigeria has continued to pose severe threats to its national integration.

In a memorandum submitted to the Presidential Committee on National Security in Nigeria (2002), it was observed that communal and societal conflicts have emerged as a result of new and particularistic forms of political consciousness and identity often structured around ethnicity and religion. People tend to form their' new and particularistic forms of political consciousness and identity from the media.

In conformity with the above thought, Dunmoye (2003), quoting Cadfy, defined violence as "physical and nonphysical harm that causes damage, pain, injury or fear." Thus, if the Nigerian press glamourizes violence and gives it more credence than necessary, the press can perform the act even if it is a 'non-physical one. This stance is informed by the understanding that the media in general and specifically the press is an avenue for various claim makers to promote their understanding of a particular phenomenon. This agitation by the various claimmakers often takes the coloration of either ethnicity or religion. Thus, if the purveyors of information, the press should also take this angle to all the issue they cover, then the conceptions of those who mostly read the product of such press may likely have a colored perception of reality. This trend may eventually stretch the bonds of unity and national integration to a potentially snapping point (Jega, 2002).

Ethnic and religious issues are part of Nigeria's body politics; the issues have permeated the landscape since the colonial period. There seems to be no solution in sight of the accompanying conflicts of ethnic rivalry and religious intolerance in the country until the present time, following the Berlin Agreement of 1885 Nigeria's official colony of the British but granted it political independence October 1st, 1960, after much struggle. The struggle for decolonization was delayed in Nigeria because there was a lack of cooperation between diverse groups in southern and northern Nigeria (Aderinto \& Akinwale, 2012).

In Nigeria, political parties so formed could not help matters as they then constituted a robust framework for decolonization. However, each party also reinforced ethnic consciousness in its domain, making it possible for Nigerians to develop a sense of divided loyalties, partly to the nation and partly to ethnic or religious groups. In 
this context, the goal of nation-building and national integration was frustrated in Nigeria, as different groups have developed the ability to mobilize their members to resist the crisis of governance in Nigeria (Aderinto \& Akinwale, 2012). Worse still, the emergent political leaders in Nigeria could not reach a consensus on the need for political independence. It was learned that the outbreak of "the Kano Riot" of $16^{\text {th }}$ to $19^{\text {th }}$ May 1953 , which led to the death and destruction of many people and property, was premised on this reason. The riot was followed by many political crises in the 1960s and 1970s, primarily due to perceived manipulations during national population census and elections. Worthy of note here is that elections in Nigeria are significant not only on the political level but also in economics (Hazen \& Horner, 2007).

Thus, the series of manipulations of the election results spurned the crisis in the 1960s, paving the way for military coups and countercoups. In Nigeria today, the dominant ethnic groups treat the minority ethnic groups with suspicion, and different religious worldviews clash at the slightest provocation. Institutional efforts made to satiate these tendencies since independence in 1960 have proved inadequate and have not yielded the desired result.

From the year 1999 to 2017 democratic dispensation, myriad crises fueled by religion and ethnicity have occurred in the country's six geo-political zones. These crises have led to the deaths of thousands and billions of naira worth of properties destroyed.

\section{Effect of Ethnic and Cultural Difference on Political Development}

The assessment of Africa's political, developmental process must be based on specific historical trajectories (Okaiyeto, 2017; Ogoanah, 2012). The history of Africa's developmental strive started from the colonial project and competition between colonial powers for access to resources, which has left some lasting impressions on the post-colonial state's evolution in Africa societal realities (Onuoha \& Qubo, 2012).

After the political independence of Africa states, it is now a reality that it was essentially a product of specific historical and geo-political developments that inform the nature of politics, economics, and society with some recorded successes (Lucia \& Aixela, 2013). Despite these setbacks, Onuoha and Qubo (2012) noted that most post-independence Africa leaders in the first two decades of independence made efforts to give meaning to the social bargain underpinning the struggle for independence.

Democracy is a political system characterized by regular and free elections in which politicians organized into political parties; compete for power by right of all adults' virtue to vote and guarantee a range of political and civil rights (Odo, 2015). The return of Nigeria to democracy in 1999 usher in enormous hope, as Ikpeaze (2013) noted that the public had reasonable anticipation of a better society.

The idea of good democracy (Morlino, 2002) entails 'freedom and equality; periodic free, fair and competitive elections have not yet been attained in Nigeria 17 years of uninterrupted democratic journey (Okaiyeto, 2017). Okaiyeto (2017) posited that the shortfall in democratic consolidation in Nigeria could not be disconnected from the historical political, social, and economic realities that define the Nigerian state since it became independent in 1960 .

Democracy in Nigeria has not provided its dividends to the people envisioned. Democracy has failed to bring good governance in Nigeria (Omoleke \& Olaiya, 2015). The election period is characterized by rigging, thuggery, violence, and money politics. These are anathema to democratic consolidation. Today, the Nigerian democracy is noted for its ethnic chauvinism, in which merit has been sacrificed at the altar of mediocrity. Thus, Majekodunmi (2012) noted that Nigerian democracy characterized by intimidation, oppression, and subordination is in most part a product of the general culture, which harbors bigotry and nepotism. As such, democracy involves values like "freedom of association, citizen participation in decision-making and nonarbitrary rule, tolerance of opposing views, respect for law and order, free and fair elections, leadership transparency, etc." lacking in Nigeria. Thus, good governance can only be realistic in Nigeria when the elites decide to embrace a truly democratic state (Adetiba \& Rahim,2012). 
African democracy, Nigeria inclusive are characterized by lack of free press, lack of free and fair elections, lack of transparency and accountability, flawed justice system, to mention but a few. These realities make African democracy scoring low in political, economic, and social performance (Afrobarometer, 2015).

Though Nigeria is experiencing some level of progress in its democratic consolidation, it can be seen that there has not been interruption for the past 17 years (Okaiyeto, 2017). The country has experienced smooth transitions and even from a ruling party to the opposition. The citizens have been demonstrating through protest both online and offline to express dissatisfaction with government actions and inactions (Osimen et al., 2013). At the same time, we are also experiencing protests in support of government policies.

Considering all these arguments, the problems of export earnings instability and terms of trade worsening for developing countries where primary products account for the bulk of their foreign sales have been frequently discussed with their adverse effects on growth (Anyebe, 2015; Ojo, 2016). This has led developing countries to consider the need to diversify their economies by developing local industries, which has been especially visible in the East Asian economies, China and India (Todaro \& Smith 2006). The underlying consideration behind diversification as a possible developmental strategy is related to the expectation of achieving stability-oriented and growth-oriented policy objectives (Pedrosa-Garcia, 2017). A broader base, coupled with a special promotion of those commodities with positive price trends, should be beneficial for growth. Hence, the value-added export commodities would be stimulated by additional processing and marketing activities (Pedrosa-Garcia, 2017). A country's degree of diversification is usually considered dependent upon the number of commodities within its export mix and on the distribution of its shares.

At this point, a significant clarification to be made is that diversification does not necessarily imply the export of manufactured goods. Agosin (2006) stated that this process might also be carried out in the form of primary commodities that evolve into natural-resource-based industries rather than into manufacturers. Indeed, Anyebe (2015) posited that commodity exports should not be associated with export concentration. Additionally, diversification has usually been related to the production and export of goods with higher skill and knowledge intensity (Agosin, 2006). A single, very visible export may also give rise to various political economy effects deleterious to growth.

The distinction between vertical and horizontal diversification is also of chief importance. The first category is related to the move between different categories of goods - e.g., the shift from primary commodities to manufactures-, through value-added mechanisms. The second category implies expanding the export basket by "diversifying into goods within the same broad category of goods" (Agosin, 2006: 7). The latter would be the case of shifting, for example, from coffee for the mass market to gourmet coffee (Agosin, 2006). Additionally, export diversification may be accomplished either by adjusting commodities in the existing export mix or adding new commodities (Pedrosa-Garcia, 2017). Hence this clarion calls for urgent diversification of the Nigerian economy. This development led to industrialization policies and economic blueprints as institutional efforts to diversify the economy and generate more revenue. Other moribund sectors are revitalized, such as mining, agriculture, telecommunication, etc. Economic diversification, in contrast, can be measurable, monitorable, and now known to be a critical component of a sustainable economy. Policymakers who want to develop sustainable economies have a target in place and have their work cut out for them.

\section{Methodology}

The study's research design was a qualitative technique of data collection and analysis. It relied on content analysis of secondary material and interviews of experts in Nigeria and Africa cultural and ethnic historical realities. The sample included ten academicians in political science and international studies composed of postgraduate students and lecturers; twenty-five informants composed of academicians in history and cultural studies, while five informants were professionals from humanities. The majority of participants were in their 
forties. Thirteen of the informants were from Ahmadu Bello University, while eight were from the University of Abuja.

\section{Findings}

\section{Factors Encouraging Cultural and Ethnic Diversity among Nigerians}

The first research question asked: Which factors encourage cultural and ethnic division the most? In Nigeria, cultural and ethnic diversity is influenced by distinctive dynamics. Such factors are present within the sociocultural, political, and economic discourse. In this study, language barrier, partisan politics, marginalization, economic deprivation, religious bigotry, indigenization policy, and illiteracy are essential factors that impact cultural and ethnic division Nigerians are battling.

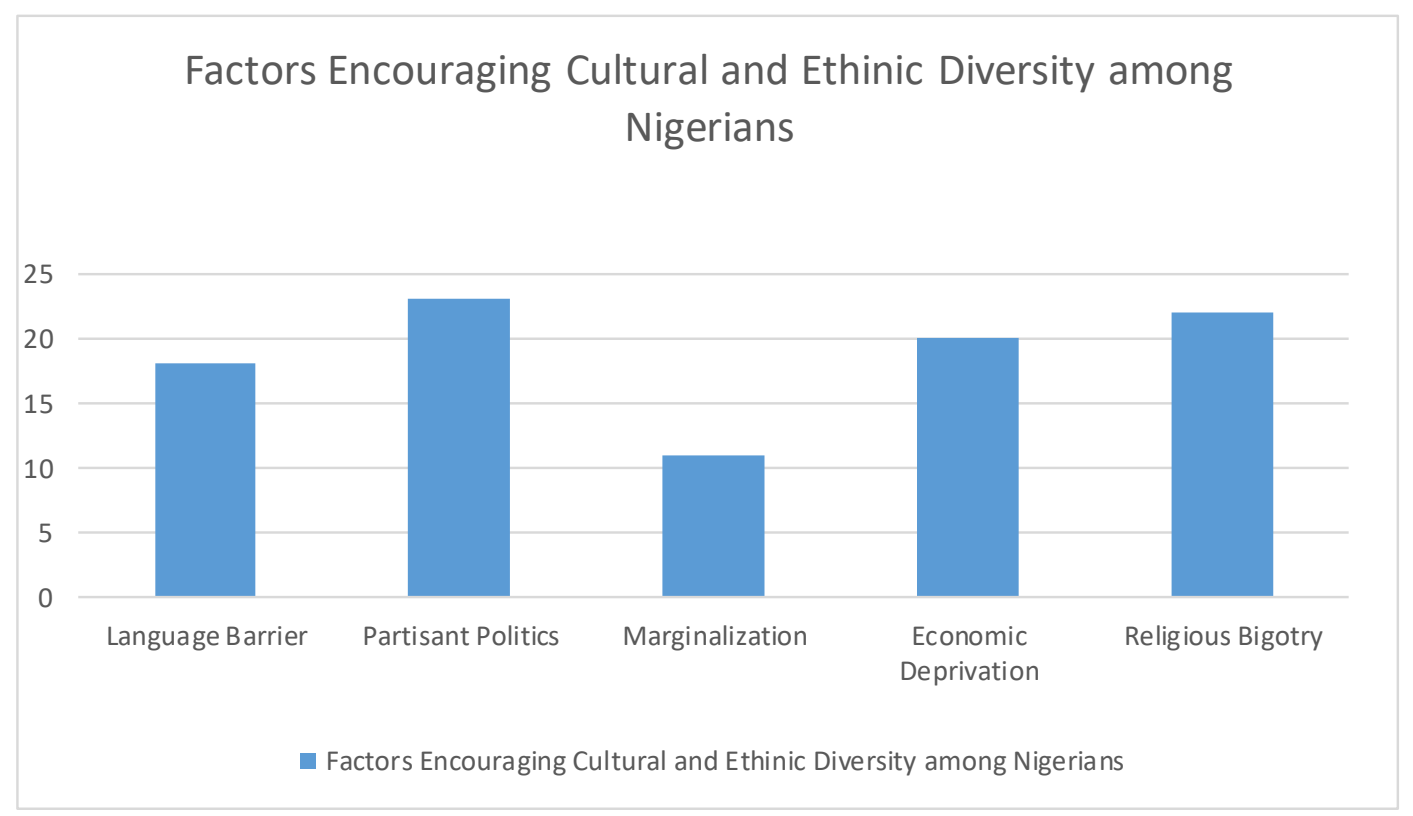

Fig 1: Factors encouraging cultural and ethnic diversity among Nigerians

\section{Language Barrier}

In Africa, the multiplicity of different spoken languages in the social, political, or economic sphere has been a significant challenge that fosters ethnic and cultural division as informants all attested.

A Professor of History noted that "the intrusion of foreign languages such as English, French, Arabic, German or Portuguese have awakened the consciousness of diversity in African languages without a common identified language as a symbol of common African identity does a humongous harm to the development of Africa as a continent, socially, economically and politically." He noted that Nigeria is a typical example of African nations with multiethnic groups which have been a severe contention for national unity. An Academician in the University of Abuja claim that "language on the African continent is a barrier to trade, integration, development and conflict resolution." Furthermore, many points support this view, for instance, the impact of indigenous languages' existence. To corroborate these claims, three informants noted that linguistic diversity fuels power 
plays and dynamics. The large groups speaking fewer languages become more powerful than the small groups speaking many languages and ethnic and cultural rivalry sources.

In an earlier study of ethnic issues in Nigeria, Basorun (2015) found that crises often erupt because of ethnic rivalry. Also, the scholar pointed that the language barrier is a cogent problem in solving ethnic tension among Nigerian communities, which Ojibara (2014) also confirmed.

Despite the proximity of Nigerian communities, most informants agreed that they hardly trade with each other; they resist rather than embrace integration and are constantly embroiled in conflict, which is usually attributed to multilingual and cultural diversity. Linguistic diversity fuels power plays and dynamics, where the large groups speaking fewer languages become more powerful than the small groups speaking many languages.

\section{Partisan Politics}

A Doctoral participant attested that "Nigeria is a country of over 300 ethnic groups with people of diverse sociocultural affiliations which have a strong bearing in its political-economic reality". A postgraduate student has known that "virtually every decision taken in Nigeria are seen from the prism of the ethnocultural divide." As such, in Nigeria, partisan democracy makes one informant observed that "political decision in Nigeria is faced with challenges centered on issues related to ethnicity, pressure from diverse socio-cultural groups, government, and corruption." One informant in the humanities discipline noted that the press is always inclined toward the politics of the day. "Ethnicity has bedeviled the Nigerian political sphere." "Politicians are tribally, regionally and religious or sectional bias in their reports of national issues." Also, three informants agreed that the Nigerian media is divided into various geo-political areas as it has been manifested in their news content.

As a Professor noted, partisan politics is a crucial player to the political and ethno-religious crisis in which, through their news, they contribute to inflammatory issues. He cited some media headlines examples that "in crises situations, headlines are sensationalized to make sales in the Nigerian media."

Political power concentration in few hands and few locations leads to personal, ethnic, regional, or sectional interest, leading to political and religious acrimony. In the same light, a political scientist observes that the 2015 and 2019 general elections portray regional sentiment dominance as determining people's choices during elections. The votes were cast along ethnic, regional, and religious identity. Here ethnic groups competing for political positions evoke the media to pass across their sentimental messages.

Studies have confirmed that Nigerian politicians are partisan along ethnic or religious lines since their independence in 1960 ( Ambe-Uva, 2010). Daramola (2013) concluded in his study that ethnicity has permeated Nigerian political structure to the extent that it is the definer of national life.

\section{Marginalization}

Linguistics at the University of Abuja aptly noted, "Uniting either as a region, ethnic nationality or religious group, the north, east, west and south southerners have adopted this method of seeking redress to perceived injustice," which institutionalized marginalization. That since the return of democratic governance in 1999, the Nigerian state has faced several nation-building challenges from separatist agitations, militancy, and ethnoreligious conflagrations from several groups. Three informants attributed these acrimonies to perceived marginalization.

An informant who is a political scientist note that ethnic question has overbearing influence in constructing political identity and power in Africa. Also, political ethnicity's influence is so pervasive and overwhelming that it has irresistibly become a fundamental contradiction despite not being the primary contradiction of society. 
This has become true of ethnicity regardless of the theoretical prism adopted to understand the ethnic phenomenon captured by one informant.

A historian posited that it now seems evident that the present system that ascribes too much power to the government at the center could not solve the myriad of political, economic, and social problems that becloud the country. Most informants concluded that the Nigerian state's crises are typically associated with class, religion, politics, corruption, ethnicity, tribalism, inadequate education, poor infrastructure, and massive unemployment. The crux now is that citizen alienation is rife nationwide, to the extent that every ethnic jigsaw component of Nigeria feels sufficiently aggrieved, marginalized, and therefore, seeks fairness via restructuring.

Abdu (2015) noticed the effect of politics of marginalization in Nigeria when he pointed that partisan politics along the ethnic and religious line and from the prism of majority-minority divides has been a threat to the county's democratic culture.

\section{Economic Deprivation}

All the informants alluded that most Nigerians are poor and lack economic empowerment; thus, they resolve to bite ethnic jingoism to court sympathy.

An economist noted that the politicization of ethnicity in multiethnic like Nigeria has to be understood ultimately in the context of intra-class struggles for hegemony within a highly fractionalized ruling class even at the detriment of the poor. Showing her frustration with the Nigerian system, one informant reiterated that "the tendency for political and social actors to draw from the emotional appeal of ethnicity, rather economic divisions make it part and parcel of the prevailing system of seeking power and authority, and a strategy of attaining material and psychological survival." Being part and parcel of the technology of power of the African ruling elite, ethnoreligious identity cannot simply be dismissed as a form of false consciousness. The ruling elite manipulates the masses for their own narrow political and economic gains, echoed three informants.

\section{Religious Bigotry}

Religion has a strong influence on Nigerians. Respondents agreed that religion is a variable that contributes to the polarization of the country. Two participants agreed that Christianity and Islam, which constitute the country's two major faith, are deciders in ethnicity.

The Historian lamented: "To say that Nigeria is divided along religion, political, economic and social fault lines is an understatement. "That these fault lines always resonate when national issues such as national census or general elections are done. One participant says that the fault lines are now in Nigeria's sub-conscious because ethnicity, religiosity, or partisanship continually defines Nigerian's dealings with one another in politics, education, or economic relations.

Much literature has documented the horrific nature of religious bigotry in Nigeria's society (Abdu, 2002; Afolabi \& Avosiloae, 2015; Onwumah, 2014). These studies have pointed out religious bigotry has been the source of crises in Nigeria for the past six decades.

\section{Ways to Manage Cultural and Ethnic Diversity for Political Development in Nigeria}

Multiethnic states must involve every ethnic group in the decision-making process for political sustainability and effective ethnic development. On this premise, this study seeks to find ways in which cultural and ethnic diversity in Nigeria can be managed. Participants were able to state how the country can manage its multidiversity for the benefit of all citizens. These measures are: protecting cultural rights, including religious and language rights of minorities, promotion of inclusive narratives and socialization mechanisms, the institutionalization of federal character, the institutionalization of democratic tenets, justice and fairness in formal and informal institutions, the establishment of the inter-religious council, the establishment of the inter- 
ethnic council, respect and tolerance of cultural differences, inter-governmental organizations and develop and adopt a legal framework for the role of traditional and religious authorities.

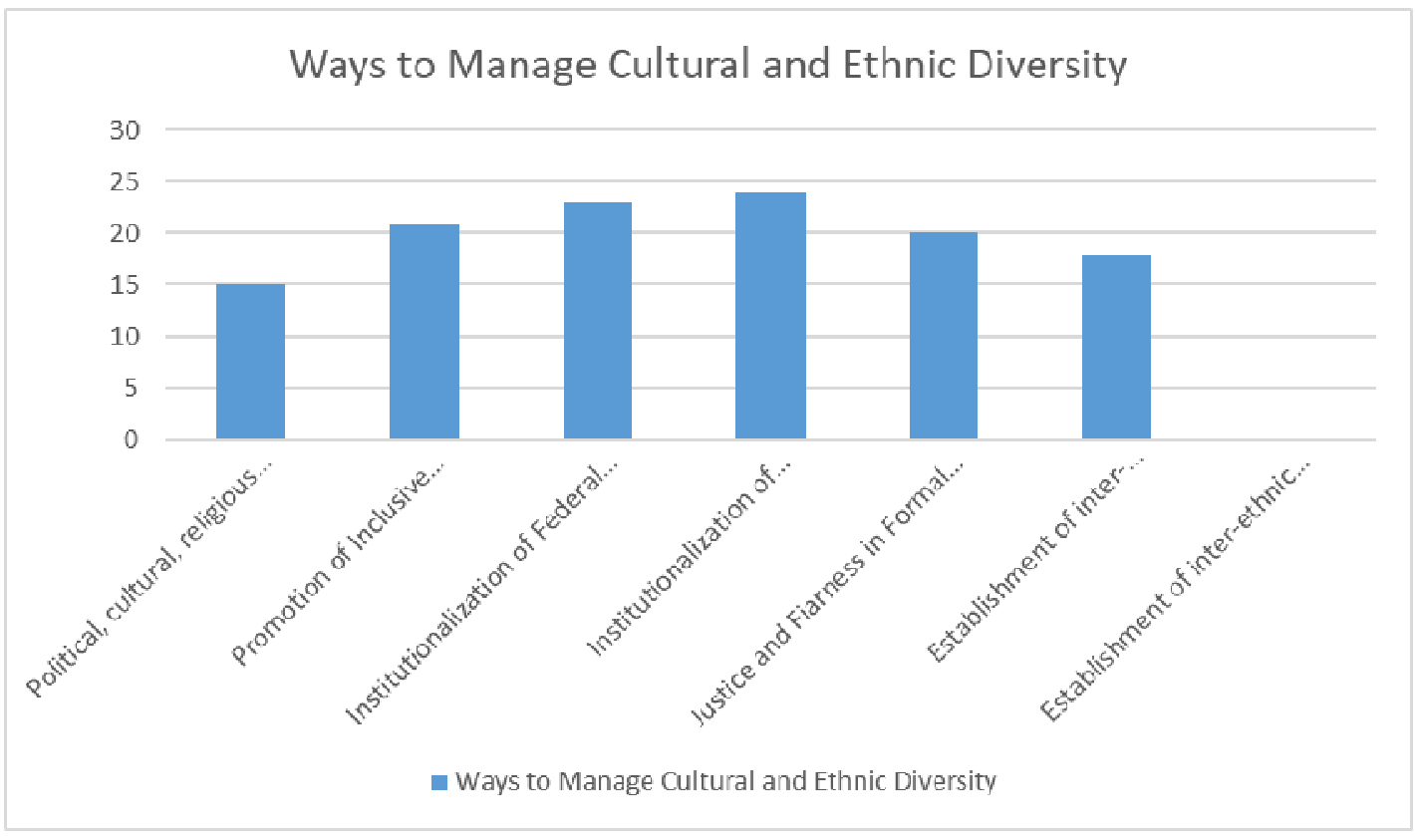

Fig 2: Ways to Manage Cultural and Ethnic Diversity

\section{Protecting cultural, religious, and language rights of minorities}

In over 200 ethnic groups and numerous religious faiths, it is common to see all these groups advocating for proper representation. This reality played out among the participants in this study as virtually all respondents showed their ethnic sentiment while responding to the question. On this premise, a Doctoral participant noted that cultural, ethnic, and language recognition narratives play a significant role in poisoning or mending identity relations among heterogeneous people. A professor of international studies reiterates that "it is important Nigerian governments use their educational systems and mass media to promote minorities right inclusive narratives. "That "such effort, though, needs to be accompanied by real commitment and effort on the part of governments to address grievances of both the majorities and the minorities." He suggested that "in the absence of concrete effort, however, narratives would likely be a source of cynicism." Therefore, protecting minorities' culture, religion, and language allows them to surrender their loyalty to the state; according to one, participants can go a long way in managing cultural and ethnic diversity in any multi-cultural society.

The Professor of Political Science echoed that minority groups in Nigeria for long have been accusing "the three major ethnic groups: Igbo, Hausa/Fulani, and Yoruba, of marginalization and negligence despite their economic contributions." For instance, "Niger Delta is a region with over forty (40) ethnic groups determine Nigeria's earnings from the oil sector to national revenue which stood at $89.1 \%$ as of 2008. In 2014, the National Bureau of Statistics also reported that oil and gas sector contribution in the third quarter of 2015 amounted to 1.944 trillion". That these "positive economic improvements are made possible by huge oil and gas deposition in the region and the paradox is that marginalization and negligence by successive governments has been attributed to the recent militancy and kidnapping in the zone." 
Afolabi and Avasiloae (2015) reiterated the importance of carrying political, traditional, and religious stakeholders and conflict prevention and resolution mechanisms in Nigeria.

\section{Promotion of $\quad$ inclusive narratives and socialization mechanisms}

"A multi-cultural society such as Nigeria needs all-inclusive narratives which play a major role in poisoning or mending identity relations among different groups." This was the position of Humanities scholar interviewed in this study. Also, a young participant pointed that "governments must use their educational systems and mass media to promote inclusive narratives." However, advocating that such effort needs to be accompanied by real commitment and effort on governments and all stakeholders to address grievances. In the absence of substantial effort, however, narratives would likely be a source of suspicion.

\section{Institutionalization of Federal Character}

The Nigerian principle of Federal Character was instituted and enshrined in the 1999 constitution with the sole aim of ensuring social harmony among tribal and ethnic groups, states, and geo-political zones. According to the Political scientist, this principle has been in existence in the 1979 constitution with improper application in the authority's decisions. The former president of Nigeria, Olusegun Obasanjo, has once said that merit should not be sacrificed on the altar of federal character principles. The Doctoral participant advised that "operations of federal character principles should be fair enough to ensure equity and fair play, merit, and competence, without losing the real essence of establishing the principle." Most of the respondents agreed that federal character is an instrument that could help manage ethnic and cultural differences in Nigeria if applied judiciously.

A couple of scholars see federalism as a panacea for Nigeria's ethnoreligious tensions (Anyebe, 2015; Majekodunmi, 2012; Suberu, 2001). Anyebe (2015) emphatically stated that true federalism is a solution to Nigeria's cultural diversity. It is through federalism that minorities will not feel being excluded in the mainstream political and economic discourse.

\section{Institutionalization of Democratic Tenets}

It is no doubt that most participants in the study acknowledged that the development of democratic institutions is essential for cultural, ethnic, and all forms of diversity management. The Professor of international studies attested that countries in Africa that recorded progress in democratizing their political systems, such as South Africa, Ghana, Botswana, Benin, and Nigeria, have made notable diversity management progress.

The Linguistic scholar recommended that liberal democracy is essential for ethnic and cultural diversity management given Africa's low-levels of nation/state-building and the fragmentation of institutional systems make it mandatory for building democratic institutions in the continent.

One participant posited that adopting consensus-based decision-making systems on critical issues guarantees economic diversification, and civil society's development creates social identities, which build bridges among primordial identities. Political parties in much of Nigeria are likely to express cultural, ethnic, or religious identities.

Scholars see democracy as the only alternative for good governance in Nigeria. For instance, Majekodunmi (2012) attributed the country's lack of development to democratic negligence. While Odo (2015) pointed that good governance can only be experienced through democratic tenants. Therefore, democratic tenets hold the key to Nigeria's overall socio-economic development.

\section{Justice and Fairness in Formal and Informal Institutions}

The ethnic, religious, and communal groups that feel marginalized by the major ethnic groups are forced to adopt constitutional and extra-constitutional means to challenge the hegemony of the major ethnic groups. Professor of Political Science noted that "the main cause of violent, identity conflict in Nigeria is that most minority groups 
have remained permanent minorities, while the majority groups are the permanent majority, a trend which has serious implications for inter-ethnic and religious relations among the diverse ethnic and religious identities in Nigeria as five informants have alluded." In this way, the incentives for cooperation, consensus, and compromise have been undermined, thereby posing an enormous challenge for the task of peacebuilding, as diverse ethnic groups are forced to co-exist in an environment of mutual mistrust, apathy and suspicion.

\section{Establishment of Inter-religious Council}

The sensitive nature of religion in Nigeria makes the country experience numerous religious motivated crises over time. As a participant put it, "religious intolerance has caused the country many harms." To foster "understanding among different religious groups, stakeholders have advocated for inter-religious council."

The Historian recalled that "The Plateau State that experiences incessant religious crises in recent time established an Inter-religious Council in 2008 to improve trust and communications between the two main religious groups in the state". "I could remember that its terms of reference charge the council with the responsibility of fostering and promoting dialogue aimed at addressing the grievances of various sectors of society. On the religious front, appreciable progress was made in engaging religious and community leaders".

\section{Establishment of inter-ethnic council}

About four Participants have seen the need for government and concern stakeholders to establish an inter-ethnic council to provide platforms that different ethnic groups will use to foster communication and promote dialogue.

\section{Factors that can Determine National Identity}

National identity in a nation-state with diverse ethnic and cultural groups is cogent in managing differences. Most of the respondents agreed that Nigeria is a much-divided country where its different ethnic groups always see reasons for deprivation. To managed ethnic and cultural diversity, participants advocated the enshrining of the following values: promotion of national symbol, promotion of national integration, promotion of public culture, recognition of minority rights, and institutionalizing citizenship.

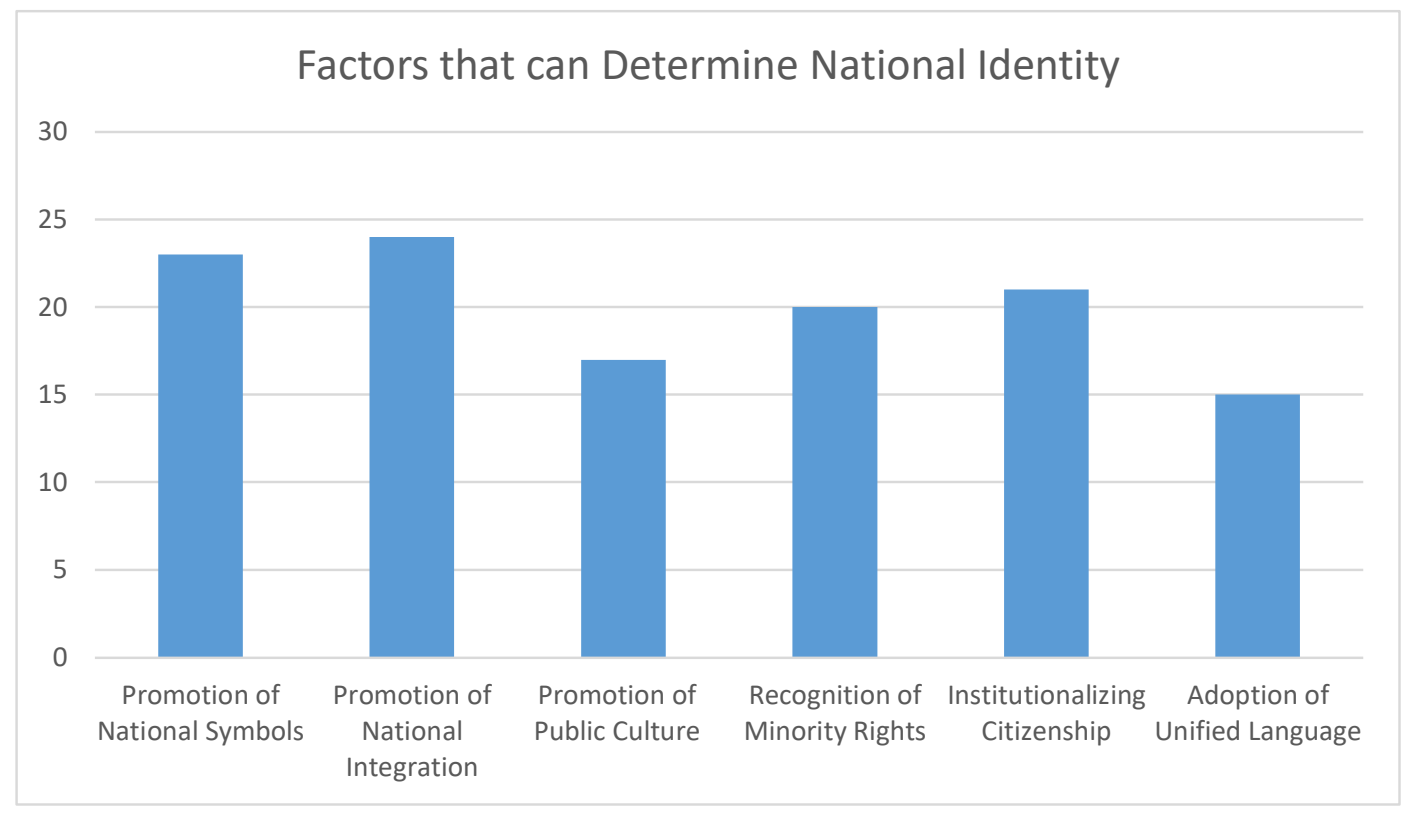

Fig 3: Factors that can determine the national identity 
The national anthem and national symbols are instruments of national identity. Unfortunately, the Historian pointed out that "Nigerians mostly glorify ethnic identity above national identity." A cross-section of participants laments that Nigerians prefer to identify themselves from their ethnic affiliation before identifying as Nigerian.

One of the Postgraduate students drew our attention to national integration in Nigeria, a situation whereby a country sees itself as a non-divisible entity to create a homogeneous society for unity and solidarity. Through national integration, the Nigerian government could bring together different state entities and make them functional.

\section{Promotion of National Integration}

In Nigeria, no doubt, one of the nation's persistent features has been the question of national integration. One participant succinctly put it this way, "where people will no longer be employed or admitted into higher institutions based on their state of origin, or where national political leaders will no longer be elected or nominated based on regional or ethnic ties."

A Political Scientist stressed that "the ethnoreligious riots all over the country, the economic and political deprivation of some ethnic groups over others; the growing national tension and insecurity, and the clamor for the increase in derivation formula; Invariably constitute the national question and have all laid siege to our national unity and severely threatened the socio-political and economic progress of our country Nigeria." Therefore, the promotion of national integration is vital in enshrining national identity in Nigeria.

\section{Promotion of Public Culture}

Public culture is that kind of way of life that appeals to most people residing in a particular environment. Since Nigeria is a heterogeneous state, most participants agreed that public culture should be highly advocated. The testimony of one intellectual participant is that "national integration in a multi-cultural state like Nigeria is unattainable without an entrenched public culture because this comprises the values shared by all groups and constitutes the common grounds on which the diverse groups conceptualize and appreciate the state."

In Nigeria, another participant observed that "groups strive to impose their particularistic definition of public culture on the entire polity in Nigeria society can easily boomerang. There is a need for a society-wide agreement that constitutes public culture to be appreciated by all sundries.

Respondents with ethnography expertise noted that "people, therefore, struggle to overthrow existing public culture rather than identify with it due to its parochialism as seen in many areas in Nigeria." That national integration and its attached benefits, like democracy and political stability, can be realized only with the development and entrenchment of a supportive public culture.

\section{Recognition of Minority Rights}

It is widespread knowledge that the majority-majority divide, majority-minority divide, and minority-minority divide are highly appreciated in Nigeria's social, political, religion, and some extend in the economic sphere. Therefore, The Historian, the Political Scientist, and the Economist's viewed the need for minority rights recognition in Nigeria as an all-inclusive decision process enshrined in the county system's psychic.

The Economist noted that ethnoreligious conflicts in Nigeria have continued because Nigerian elites are corrupt and split along religion and ethnic divide. This "has resulted in ethnic rivalry, suspicion, and hostility among leaders both within majority-majority divide, majority-minority divide, and minority-minority divide."

The Political Scientist is clear here that "without a bold and articulate leadership, conflict management, prevention, and national integration, will always be a mirage." 


\section{Institutionalizing Citizenship}

The Nigerian leadership, "though are very much aware of the indigene problems or not; have to muster the courage to foster serious discussion of key issues such as indigenousness and citizenship, which can only be addressed through constitutional reform." These were the words of one participant. Another respondent pointed that "Nigerians that settled in another environment other than their state of origin or the one born in a state different from the state of his origin are always finding it difficult to integrate with the host community." "This issue becomes more precariously entrenched along different ethnic or religion lineage." The Historian gave this account "lots of violent crises have been recorded in the last six decades that are very related with indigenecitizen dichotomy." "On top of this problem is citizen alienation nationwide; to the extent that every ethnic jigsaw component of Nigeria feels sufficiently aggrieved, marginalized and therefore, seeks fairness via restructuring."

Also, citizenship and indigenization defining Nigerians dealing with one another is a problem to national unity. One participant understood that the most frustrating is "federal government-owned institutions which in several cases are 'captured' by the host community treating workers from other parts of the country as aliens both in attitude and conduct."

\section{Adoption of Unified Language}

Communicating in the traditional multi-linguism is so common in the country, as observed by one respondent. "Many of us in Africa can speak or read or write apart from Africans' mother tongues, but in different national and official languages of our countries. Both native and colonial languages such as Arabic, Amharic, Yoruba, Igbo, Hausa, Swahili, English, French, and Portuguese are common. The same goes for one or more neighboring languages. One other lingua franca which is operative in government circle or as a commercial or trading language or even among students in schools, in police/army domain, in mosque/church, railway or mine, and port workers' languages, etc." respondent stressed that is "really an issue to contend with in this $21^{\text {st }}$ century of interdependence among countries".

A Historian made this analogy "assuming that the individuals that migrated together must have spoken the same language." That "speaking the same language enabled them to support or cooperate during and after the migrations, regardless of whether or not they formed well-organized political groups." They equally had ethnic or racial affiliations that had set them apart as distinct groups, and these linguistic-cultural milieus can serve as a source of the bond among the people.

Multilingualism, one participant saw it as a liability and a burden, mainly when considered in the context of the number of resources needed to promote the use of multiple languages in the domains of governance, law and administration, business and commerce, education, media, and international communication, among others. Therefore, a unified language is necessary for the easy and less complex administrative procedure.

Another participant noted that "the presence of many languages is also equated with economic backwardness while the existence of one language for the whole nation is associated with economic prosperity and political stability." It is "suffice to note that it is tough to appreciate the rationality of an argument against multilingualism in the name of economic prosperity because there is no direct connection between economic success and unilingualism."

However, it is essential to consider a unified language for easy interaction among multi-cultural and ethnic societies like Nigeria. The cultural and ethnic division has always been a source of tension among the people. 


\section{Conclusion}

Nation-building for national development can be very daunting, especially in countries deeply polarized along ethnic and religious fault lines. This study has demonstrated that ethnic and religious identities, in themselves, do not ferment or condone violent conflicts. Instead, beneath conflicts that are often regarded as ethnoreligious are questions of disproportionate access to power, scarce resources, and opportunities. Moreover, the issues that generate the fiercest contestations are considered fundamental to the state's survival and reproduction, over which competing groups tend to adopt exclusionary, do-or-die approaches. These include control of state-power, resource allocation, and land.

For example, factors such as poverty, political and socio-economic marginalization, weak state capability, and lack of good governance were all implicated in the cities of Northern Nigeria where conflicts have contributed mainly to ethnic, religious, and citizenship politicization of identities, thereby leading to their fundamental isolation and political salience. Such identities tend to become problematic when access to opportunities in the political system in terms of power and resources are dependent on membership of a particular ethnic or religious group and when the state is weak in terms of its capacity to protect its citizens and provide for their welfare.

In conclusion, this study has alluded to identity construction and its fundamentalisation in accentuating ethnoreligious and political conflicts. It has focused on the development, diversity, density, and trajectories of identities and identity conflicts in Nigeria while centering its analytical praxis on the recurring conflicts multiple states across the country. It is plausible that the goals and interests that all the groups in the affected communities pursue are rooted in the quest for access to power, and opportunities via patronage and clientelism can only be gotten through state machinery. In the process, the privatization of violence and the manipulation and mobilization of ethnic religious and citizenship sentiments are often freely employed by the competing groups. Also, in proffering solutions to the ethno religious and political conflicts, there is need for localization of solutions by constantly engaging traditional and religious institutions at the grace roots. Since all politics are local, there will a spiral effect of the local engagements to the sub national, national and regional level.

\section{References}

Abdu, H.(2002). "Ethno-Religious Crisis in Kaduna: Impact on Women and Children." Ethno-Religious Conflicts and Democracy in Nigeria: Challenges. Eds.Etanibi Alemika and Festus Okoye. Kaduna, Human Rights Monitor, 117-142.

Adetiba, T.C. \& Rahim, A. (2012). Between ethnicity, nationality, and development in Nigeria.

International Journal of Development and Sustainability. 1 (3), 656-674.

Afolabi, B. and Avasiloae, S. (2015). Post-election assessment of conflict prevention and resolution mechanisms in Nigeria. Report for Center for Humanitarian Dialogue, Nov. 2015

Afrobarometer (2015). African democracy update: Democratic satisfaction remains elusive for many. Afrobarometer Dispatch No. 45

Ambe-Uva, T.N. (2010) Identity politics, and the Jos crisis: Evidence, lessons, and good governance challenges. African Journal of History and Culture vol. 2(3), pp. $42-52$.

Anyebe, A.A. (2015). Federalism as a Panacea for Cultural Diversity in Nigeria. Global Journal of HUMANSOCIAL SCIENCE: Sociology \& Culture, 15 (3), 15-24.

Ayatse, F. H \& Akuva, I.I(2013). The Origin and Development of Ethnic Politics and Its Impacts On PostColonial Governance In Nigeria. European Scientific Journal, Vol.9, No.17, 178-189. 
Basorun, M.A. (2015). An analysis of the reportage of Jos crisis and Boko Haram insurgence by selected Newspapers. A Thesis Submitted to the School of Post Graduate Studies, Ahmadu Bello University.

Daramola, I. (2013). Ethnic consideration in political coverage by Nigerian media. Kuwait Chapter of Arabian Journal of Business and Management Review, 2(12), 39-52

Darden, K. \& Anna Grzymala-Busse, A. (2006). "The Great Divide: Literacy, Nationalism, and the Communist Collapse." World Politics, Volume 59 (October): 83-115.

Deutsch, K.W. \& Folt,W.J. (eds,). (1966). Nation Building in Comparative Contexts. (New York, Atherton), retrieved on January 19th, 2016 from https://en.wikipedia.org/wiki/Nation-building.

Dunmoye,R.A.(2012).ComplexityofEthno-ReligiousConflictsinNigeria:Interfaceof SecurityandDevelopment.BeingapaperpresentedattheHumanitiesInternational ConferenceonNationalSecurity,IntegratedandSustainableDevelopment.Organised byFacultyofSocialSciencesAhmaduBelloUniversityZaria.InCommemorationof the $50^{\text {th }}$ Anniversary of Ahmadu Bello University Zaria.

Edewor, P.A., Yetunde A. Aluko Sheriff F. Folarin. (2014). Managing Ethnic and Cultural Diversity for National Integration in Nigeria. Developing Country Studies, 4 (6), 70-76.

Egwu, S. (2007), "Power Sharing, Political Stability and Ethnicity in Africa," in Bassey, C.O. and Oshita O.O. (Eds.), Conflict Resolution, Identity Crisis and Development in Africa, Malthouse Press Ltd, Lagos, pp. 97-111.

Irobi, E. (2013). Ethnicity and Nation Building in Contemporary Africa: A Perspective for Nonkilling. Global Nonkilling Working Papers

Jega, A.M (2002) Education, Democracy and National Integration in the 21st Century. The African Symposium: An Online Educational Research Journal, Vol.2, No.4.December.

Mohammed, M.I. (2013). Hausa Film: Compatible or Incompatible with Islam and the Hausa Culture? Retrieved September 12th, 2016 from http://kadunavoice.com/hausa-film-compatible-or-incompatible-with-islam-and-thehausa-culture/\#sthash.XzCO2awA.dpuf

Obateru, T.(2011) "We Warned That Jos Riot Was Coming - Varsity Don." Vanguard [Lagos] December 8th, 2011: 14. Print.

Odo, U.L. (2015). Democracy and good governance in Nigeria: Challenges and prospects. Global journal of Human-Social Science: For Political Science,15(3 ), 1-8

Odeyemi, J.O (2014) A Political History of Nigeria and The Crisis of Ethnicity in Nation Building. International Journal of Developing Societies.Vol.3, No.1, 87-95. Ogoanah, F (2012). The Evolution of National Vocabulary in Nigeria: Implications for National Cultural Integration. Language Matter, 43:2.

Ojo, O.V. (2016). Ethnic diversity in Nigeria: A purview of mechanism for national integration. Afro Asian Journal of Social Sciences, VII ( III Quarter III) 2016, 1-113.

Ojukwu, C.C., and Onifade, C.A. (2010) Social capital, indignity and identity politics: the Jos crisis in perspective: African Journal of Political Science and International Relations. Vol 4(5) pp. 173 -180.

Okaiyeto, S.A (2017). Political Inclusiveness in Nigeria Democracy: An Appraisal of \#NOTTOYOUNGTORUN Campaign on Social Media. The Role of ICT in Higher Education and Globalization. Paper Presented at the Post Graduate School in Conjunction with Postgraduate Student' Association, University of Ilorin $1^{\text {st }}$ International Conference. November 7th, 2017. 
Okpu, Ugbana (1977). Ethnic Minority Problems in Nigerian Politics: 1960-1965. Stockholm: LiberTryck AB, 1977.

Olayinka, A.P, Florence, T.T, Idowu, A.A , Ewuola, P.O and Aderemi, A.S (2015). Impact of Mass Media in Conflict Resolution. International Journal of Advanced Academic Research. Vol. 1, (1) 1-22

Olayoku, P.A (2014). Trends and Patterns of Cattle Grazing and Rural Violence in Nigeria (2006-2014). IFRANigeria working papers series, $\mathrm{n}^{\circ} 34$ 28/11/2014

Omotoso, S.A and Rasaq, D.O (2015). Exploring idealistic-pragmatic approach in evolving strategies for ethical conflict reporting in Nigeria. In Isola, O. O and Popoola, M (Eds). Journalism Practice and Terrorism in Nigeria: Issues, Trends, and Techniques. Ibadan: John Archers Limited. Pp 132-151

Onuegbu, E.N. (2012). Print media coverage of religious crises in Nigeria (a study of Daily Trust, The Guardian, The Nation, and The Sun newspapers). A Dissertation submitted to the Department of Mass Communication, University of Nigeria, Nsukka

Onwumah, A.C (2014). Communal and Ethno-Religious Crises and their Implications for National Development in Nigeria. Developing Country Studies. Vol.4, No. I? Pp. 126-

Osae-Brown, Anthony. "Mathematics of Winning the Presidential Polls." Business Day, April 14th, 2011. Available from www.businessdayonline.com/NG/index.php/news/111-politics/20483-mathematics-of-winningthe-presidential-polls.

Osimen, G. U, Balogun, A. \& Adenegan, T. S. (2013). Ethnicity and identity crisis: Challenge to national integration in Nigerian. IOSR Journal of Humanities and Social Science, 16 (4), 79-86.

Sá Lúcia, A. \& Aixelà, Y. (2013). Cultural Diversity in Africa: Colonial Legacy and Construction of Alternatives. Introduction. Nordic Journal of African Studies 22(1\&2): 1-5

Seemndze, L.M. (2016). Politicization of Cultural Diversity and Its Impact on Nation-Building in Cameroon: A Political Philosophical Analysis. Africology: The Journal of Pan African Studies, 9 (4), 158-175.

Thomson, A (2000). An Introduction to African Politics. London: Routledge.

Todaro, M. \& Smith, S. C. (2003). Economic Development (8th edition). India: Pearson Education (Singapore) Pte. Ltd. Indian Branch. 